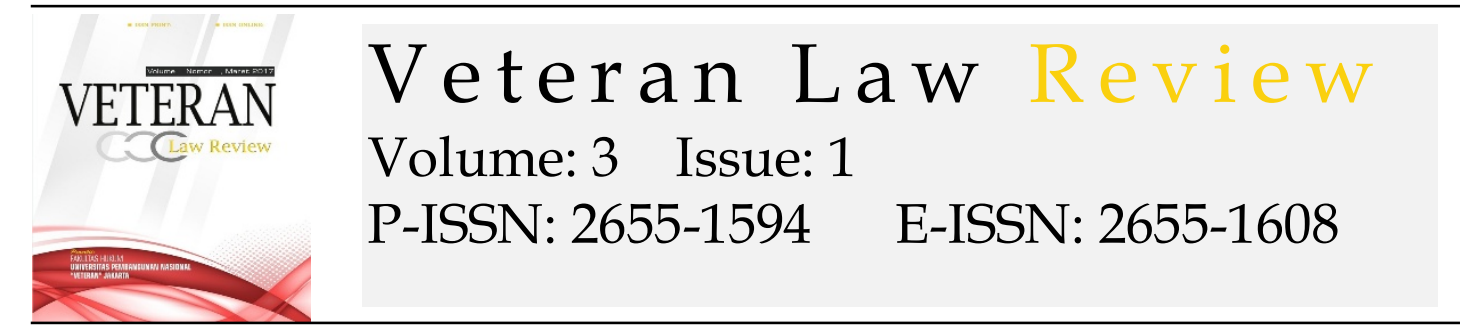

\title{
Provision of Rehabilitation of Drug Addicted Children as a Form of Fulfillment of Constitutional Rights
}

\section{Fransiska Novita Eleanora}

Faculty of Law, University of Bhayangkara, E-mail:fransiska.novita@dsn.ubharajaya.ac.id

\begin{tabular}{|c|c|}
\hline ARTICLE INFO & ABSTRACT \\
\hline $\begin{array}{l}\text { How to cite: } \\
\text { Eleanora, F.N. (2020). } \\
\text { Provision of Rehabilitation } \\
\text { of Drug Addicted Children } \\
\text { as a Form of Fulfillment of } \\
\text { Constitutional Rights } \\
\text { Veteran Law Review. 3(1). } \\
\text { hlm. } 45-55\end{array}$ & $\begin{array}{l}\text { Protection of children is a duty and also the responsibility } \\
\text { of all stakeholders, because protection is to provide a sense } \\
\text { of security and comfort for him to be able to carry out all } \\
\text { his activities or activities without any obstacles or actions } \\
\text { in the form of violence, and discrimination to cause } \\
\text { children to become victims. Including children as } \\
\text { perpetrators of narcotics in addition to getting recovery } \\
\text { in the form of rehabilitation and because of protecting } \\
\text { children and avoiding negative stigma to children, the } \\
\text { resolution of the dispute is carried out through a } \\
\text { restorative justice approach that is diversified by seeking } \\
\text { justice between victims and perpetrators. The problem } \\
\text { that will be examined is whether with this restorative } \\
\text { justice approach can resolve child disputes relating to } \\
\text { narcotics crime as a form of fulfillment of the child's } \\
\text { constitutional rights, namely by providing rehabilitation } \\
\text { is a form of child conviction. The research method used is } \\
\text { a conceptual approach with a conceptual approach use } \\
\text { existing views or doctrines, principles and legal concepts, } \\
\text { and also refer to primary, secondary and tertiary legal } \\
\text { materials. The result is that the concept of restorative } \\
\text { justice approach can provide justice because it involves } \\
\text { the community, perpetrators and victims of disputes and } \\
\text { focuses on restoring the original condition and children } \\
\text { as narcotics do not get a stigma that is ugly or known to } \\
\text { the public and thus can also be done with treatment and } \\
\text { rehabilitation measures. } \\
\text { Copyright @2020 vELREV. All rights reserved. }\end{array}$ \\
\hline
\end{tabular}

1. Introduction

Indonesia as a state of law certainly recognizes the guarantee of the protection and upholding of human rights, which is stated in the provisions of Article 1 of the Law on Human Rights, namely Number 39 and 1999 
which states that human rights are a set of rights which is also attached to the nature and existence of human beings and as Creatures of God Almighty and also is His gift and must and must be respected, and also upheld and protected also by the State, the Government and the Law and also anyone and also everyone and also for the sake of respect for the protection of human dignity and dignity. So that in this article there is a guarantee and recognition of its citizens and is a form of protection of the existence of constitutional and essential rights and contained in the constitution ${ }^{1}$ namely the constitution and 1945.

Recognition and guarantees are also given to all citizens and there is no difference or discrimination including to minors, where minors commit a crime and as a perpetrator must be given a special protection against it, the specific protection referred to is the protection will be towards businesses ${ }^{2}$ in ensuring the growth and development of children, so that they become children who are in accordance with the hopes and ideals of a nation and become a generation and successor. In reality today, many children who consume drugs as a place to release frustration or stress, or families who do not pay attention anymore (broken home), even trial and error or are influenced by friends, and many other reasons, so easy things these are consumed so that children are also ensnared and are not spared from their parents' supervision, because if they already consume these narcotics then they continue to feel resilient and difficult to release them.

Referring to the Law on Narcotics of 2009 with Number 35 in the provisions of the article in paragraph 54 , that it is stated that addicts from narcotics and victims of abuse of narcotics must undergo medical and social rehabilitation. Medical rehabilitation is very much related to treatment and also recovery to health, while social rehabilitation is related to social recovery from the mentality of the drug addict, and based on the provisions in article 55 it is also stated that when making a request for rehabilitation by the addict himself and his family to institutions in rehabilitation that are medical and also social. Whereas against and for addicts for underage drugs, the guardian himself reports ${ }^{3}$ Drugs as substances from hazardous substances are very easy to damage the brain and other nerve tissue and will certainly damage the circulation of the system in the body and have an impact on death, so that children who are proven to be addicted to drugs should not be sanctioned or punished but given medical rehabilitation and social in order to be able to recover as before, and to carry out activities or activities as before ${ }^{4}$.

1 Wiryono Prodjodikoro,( 2003), Tindak-Tindak Pidana Tertentu Di Indonesia, Bandung : Refika Aditama, page. 11

2 Asep Syarifuddin Hidayat, Samul Anam, Muhammad Ishar Helmi, (2018), Perlindungan Hukum Terhadap Anak Sebagai Kurir Narkotika, SALAM ; Jurnal Sosial dan Budaya Syar-i, 5 (3), page, $310-311$

${ }^{3}$ Kusno, Adi, (2009), Kebijakan Kriminal Dalam Penanggulangan Tindak Pidana narkotika Oleh Anak, Malang : UMM Press, page. 51

${ }^{4}$ S. Amdinat, (2005), Upaya Pencegahan Narkoba Terhadap Anak Didik, Pekan baru : UNRI Press, page, 18 
The provisions in the Law on the juvenile justice system of 2012 under number 11, the third article with the letter $\mathrm{g}$, states that not arrested, or imprisoned or detained except as the last resort and in a short time, meaning a child, if as drug addicts instead of being imprisoned, because by being in prison instead of stopping taking drugs but already really in a very addictive stage, and in the end the children will suffer. By carrying out rehabilitation, there will be efforts from law enforcement and the government to protect and save and prevent children from avoiding drugs, and in this case must synchronize with legal aid agencies and other social institutions ${ }^{5}$.

Rehabilitation provided is also a protection of children's rights in accordance with the provisions of article 59 of the Law on the Protection of Children, namely Number 35 of 2014 concerning Amendments to Law Number 23 of 2002, which states that the 1st, the government, and the regional government as well as other state institutions are obliged and responsible in providing special protection to the children, and the second paragraph specifically protection for children as referred to in paragraph (1) is given to, paragraph which ( e) Children who are victims of abuse of narcotics and alcohol, as well as psychotropic substances and / or other addictive substances, which in the provisions of article ${ }^{6}$ to 59A, that special protection is given by handling it really quickly, and is included in the treatment and / or rehabilitation both physically, psychologically, as well as socially, as well as the prevention of diseases and the existence of other health problems and also assistance to psychosocial treatment at the time of recovery.

Children as perpetrators of criminal offenses namely the abuse of medical and social rehabilitation narcotics, besides that of course protection of children's rights is not solely as an offender punished, but also provides solutions through approaches to justice in a restorative justice to children as perpetrators of criminal acts with the aim to restore the rights or conditions as before, with the application of this restorative justice concept, the child as a behavior is protected by his good name and does not give him a negative view of society. This the implementation of children can also undergo treatment with medical rehabilitation that is through medicine and medicine and socially can be returned and accepted back in their neighborhood, this concept provides justice for children as perpetrators or victims in obtaining their constitutional rights especially for children dealing with the law, with the restorative concept, the granting of rehabilitation is punishment as well as healing the dependence of narcotics, as a form of diversion.

\footnotetext{
${ }^{5}$ Budi Prawoto dan Intari Dyah Pramudita, (2008), Narkotika dan Zat Adiktif, Jakarta : Sinar Grafika, page, 17

6 https://www.hariansilampari.co.id/ratusan-remaja-direhabilitasi-narkoba/ "ratusan remaja direhabilitasi narkoba" diakses 26 Januari 2020
} 


\section{Method}

The research method used is a conceptual approach with the emergence of new ideas that are seen from the point of view of knowledge and are used in identifying views, as well as existing doctrines as well as generating new arguments, which in reviewing them are seen from the legal material primary, secondary and tertiary ${ }^{7}$

\section{Main Heading of the Analysis or Results}

\section{Understanding of Minors}

Many regulations that mention and give the term for minors, some explain with age restrictions with a variety of different meanings, but in the law on the protection of children stated that children are aged with a maximum of 18 years and a minimum age of 8 years, with the explanation is that a child must be able to be given protection of the fulfillment of his rights including if a child commits a crime, or a child who commits an act in consuming drugs or other addictive substances, must be given protection of his constitutional rights. Protection of children as perpetrators or drug users also starts from the time the child is detained, but solutions must be sought or solutions that are appropriate for the child, while in the investigation stage must be treated humanely, meaning that there is or can be done other legal remedies than should imprisoning a child or holding a child in prison.

Because children as the generation of the nation's successors who will continue the ideals of the nation's struggle, at least there is a last resort, besides prison, or can be implemented with diversion towards restorative justice, but for children who are found out or caught consuming drugs must also be restored so that the situation can recover and return to normal, the state of recovery and return to normal as before like never having done or consumed or even consumed the drug, so the child can carry out activities and activities like children in general such as, school, learning, playing and recreation ${ }^{8}$ not just put it in a prison cell, because it will cause pain and addiction to drugs becomes more so that in the end the child will be depressed and can end his life due to no recovery or treatment.

Efforts to implement the protection of children's rights can be carried out optimally by promoting the constitutional rights of children and looking for the best interests of children, in order to ensure the fulfillment of children's needs and lives, children's rights should also be respected when dealing with the law, must be avoided from any acts of violence and torture and are entitled to obtain or obtain legal assistance to protect their rights. It also does not necessarily imprison a child if it

7 Peter Mahmud Marzuki, (2009), Penelitian Hukum, Jakarta : Kencana. page. 33

8 S. Amdinat,(2005), Upaya Pencegahan Narkoba Terhadap Anak Didik, Pekan baru : UNRI Press, page. 23 
is proven to have committed a crime or a mistake because other methods will be pursued to provide sanctions and deterrent effects to the child, especially if the child is proven to have been addicted to drugs, there must be a recovery of his physical, psychological and social integration. ${ }^{9}$

\section{Drugs, Factors and Impacts}

Or better known by the abbreviation of narcotics, also psychotropic and addictive substances or substances are know something that can be entered into the body in humans in the form of materials or substances, which are carried out in various ways, namely drunk, also inhaled, and also injected in the body, which where the impact will be changes and then the mood can change, the mood and heart also change and someone will also change their behavior. Drugs besides damaging health can also damage other nerve cells and if addiction or addiction can cause death, by taking this drug often seen significant changes, such as halting, the occurrence of changes in blood cells in the brain, dehydration and behavior of the user is often seen more aggressive and confusion and loss of memory, sometimes unconscious, and often seizures due to excessive overdose and death ${ }^{10}$ Drug use has mushroomed not only used by children or consumed by them, even has reached the parents and not only national but has international level, such as morphine and heroin also cannabis and methamphetamine, Cocaine and others, supervision of the entry the circulation of drugs must be tightened because it is clear that by consuming this item, not the peace that is obtained will damage the generation of the next generation of a nation. ${ }^{11}$

\section{Whereas there are several factors that get pushed why a child gets caught up in drugs :}

a) Lack of harmony in the family, the family is a place of care and love and a place for complaints of children to their parents, but when the family breaks up divorce and the child becomes neglected can lead to things that are not desirable, depressed children and seek escape with drug consumption with the hope of being able to recover, besides that the parents are too busy and not paying attention to their children also bring children to take drugs.

b) Promiscuity, carried out because there is a lack of supervision and attention from their parents, never seeing and paying attention to who their children associate with whether children are good or not, so that children are dragged into

9 Tamutiene, Ilona, (2018), Alcohol-Related Child Maltreatment : Reports to the Child Rights Protection Services in Kaunas Municipalit, Nordic Studies on Alcohol and Drugs : SAGE Journals, vol. 35 (1), page, 9-23

10 Novitasari, Dina, (2017), Rehabilitasi Terhadap Anak Korban Penyalahgunaan Narkoba, Jurnal Hukum Khaira Ummah, 12 (4) 2017, page, 920

11 Campa, Adriana, Sabrina Sales Martinez and Marianna Baum, (2017), Drug Addiction, Relapse and Recovery, Journal of Drug Abuse, vol. 3 (1:4), page, 1-2 
promiscuity, such as sex, also drugs, alcohol and also smoking.

c) Want to try, feel curious and want to know how the name of the drug, and it feels, needs to be done with socialization and counseling, the impact if the drug is consumed, so the child does not want to try or feel curious about the object called the drug.

\section{Negative effects of drug abuse :}

(i) There is a change in attitude and personality

(ii) The decline in the values of discipline and also lessons

(iii) High emotional nature and even uncontrolled

(iv) Being a person who tends to be lazy

(v) Endanger themselves and also their health

(vi) For the sake of drugs, they are willing to commit criminal acts $^{12}$

\section{Medical And Social Rehabilitation}

The definition of rehabilitation in general is to rehabilitate or heal or restore a person so that he can return to his original state, and can also be explained rehabilitating the actual aims or hopes so that those who have been treated can carry out or carry out activities as before, this is also in line with using the methods the way not to convict someone if it turns out to impose sanctions actually results in further suffering, so it is best to do rehabilitation methods ${ }^{13}$. This rehabilitation is also intended for children as addicts or users of drugs, and in this rehabilitation there has been a decision from the judge not to convict the child but provide rehabilitation efforts, where rehabilitation is meant by medical rehabilitation ${ }^{14}$ and also with social rehabilitation, because it is in line with the protection of children, which prioritizes their right to always be able to grow and develop, if given or imposed with imprisonment, then what will emerge is the stigma or stamp attached to the child, where the stigma or The stamp will always stick to adult children, especially if the community or the environment knows, have been held in prison, and to eliminate it, so that more mitigating methods are used, namely rehabilitation if the child is proven to be an addict or user of drugs. If it is done with diversion through restorative justice, it can also be done but the crime committed is seen first, if for diversion it is usually against children who have problems with the law, as perpetrators of the crime, it seems impossible to be given diversion, because the child does not commit a crime but consumes drugs.

12 https://www.galamedianews.com/?arsip=214151, "Dampak Negatif Penyalahgunaan Narkoba", diakses, 24 Januari 2020

${ }^{13}$ Lichtblau Craig, Keith J Foster, Gabriele Melli, Charles H Hennekens (2019), Physical Medicine and rehabilitation: The Case For Physiatrists, International Jaournal Physical Medicine Rehabilitation, Vol. 7 (2), page, 1-3

14 Yuli Andriansyah, Lalu Abdurrahman, (2013), Penyuluhan Pencegahan Bahaya Narkoba Terhadap Anak-Anak Usia Dini, Jurnal Inovasi dan Kewirausahaan, 2 (2), Seri Pengabdian Masyarakat, page, 105 
So as to protect from children as stipulated in the regulations on the protection of children, and also the law regarding the court of children, which has been revised with the law on the juvenile justice system (SPPA) in 2012 and numbered 11, it is written that children who use narcotics, and other addictive substances should instead be given protection that is special indeed means protection that is really special for children, so that children can recover later as usual. There are 2 kinds of rehabilitation given, namely medical rehabilitation, that is, in a medical or medical way, namely by using drugs to be able to heal, based on examination and treatment from the medical world, where the capacity as an expert witness, it can be reviewed and seen to what extent the addiction of the child, the doctor who is asked to examine and see the condition of the patient or child will notify the judge regularly through the investigator, at what level of disease or addiction experienced by the patient or child who is addicted, by giving drugs the goal of the drug is to provide a healing effect and can stop taking the drug 15

While towards social rehabilitation, the child or patient is a process of refinalisation and also development to enable a person to be able to maintain his recovery and also be able to carry out his social functions and functions properly in the life of the community, and this is very relating to institutions of social welfare in society that provide for the implementation of welfare that is formed for harmony by the community. Social rehabilitation is carried out in several stages, namely:

a) The initial approach, which is to see how the child, whether it can forget or not the problem

b) Disclosure and understanding of the problem, by realizing for yourself why to consume drugs and the factors that influence it.

c) Compilation of plans for solving existing problems, carrying out steps or initial steps so that problem solving can be resolved, goals and objectives so that they do not fall back on drugs ${ }^{16}$

d) Solving the problem, seeing what factors that influence the problem and how to overcome it whether it must involve many aspects or not.

e) Resosialisation, preparing to become a better person, by forgetting the problem the child is expected to return to his new environment, and start his whole life from scratch.

f) Termination, a point from the end of the process of change, where this stage is very disturbing because the child will be in trouble and start to have a change.

g) Guidance and continuation, where in this stage everything can go as expected means, the child continues to be guided gradually until completely recovered and normal as before

15 Mardani, (2005), Penyalahgunaan Narkotika Dalam Perspektif Hukum Pidana Islam dan Hukum Pidana Nasional, Jakarta : Raja Grafindo, page, 28

16 Sri Purwatiningsih, (2001),Penyalahgunaan Narkoba Di Indonesia, Populasi Jurnal Kependudukan dan Kebijakan Universitas Gadjah Mada, 12 (1), page, 41 


\section{Fulfillment of Children's Constitutional Rights}

Constitutional rights which are the rights of Indonesian citizens where those rights have been contained in the constitution will be opened in the 1945 constitution, in the provisions of article 28 it is stated or stated that, the poor and displaced children are maintained by the state, by observing these provisions the implied meaning is that the state guarantees the lives of its incapable citizens and seeks to protect it from any threats and obtain its rights such as education and teaching, and health as well as other rights included in the right to life ${ }^{17}$ Fulfillment of constitutional rights is also specifically regulated in a law that is the law concerning human rights from humans where in the regulation it is explained that human rights have been recognized by the state because it is a gift from God Almighty and everyone without exception must always respecting and respecting and upholding these rights, and everyone in obtaining their rights must be treated equally and appropriately and no arbitrary or arbitrary actions from other parties or acts of discrimination ${ }^{18}$

Every person must not be said to be guilty before having permanent legal force in pleading guilty or not from court (inkracht), and to declare someone guilty or not must be accompanied by sufficient strong evidence, that is, with evidence and also evidence, as long as it is not If this is fulfilled, it cannot be said that the person is guilty, and whoever does not have the right or authority to convict or impose sanctions or punishments on that person, in line with that Indonesia is called a country based on law, and adheres to the principle of legality, anyone who is guilty without looking at anything must be punished without exception. However, there are exceptions in sanctions such as the basics of punishment, and it must also be seen that sanctions are the last resort, and should also be seen in what cases or criminal acts the sanctions were given, and whether they had a deterrent effect on the perpetrators or no, this matter that needs to be examined and reviewed, for example with a criminal act of narcotics or drugs turns out to be given sanctions in the form of a criminal turned out to cause suffering or even death may not be given again, both to adults or even children.

Children as drug addicts in protecting the constitutional rights give great effects and benefits where the child can become a private person well, by not convicting him but instead giving him actions in the form of rehabilitation to restore his condition, his recovery here involves psychiatric, psychological and physical as well as psychology. start again from beginning to end in carrying out activities or activities as usual and can recover as usual ${ }^{19}$ By providing rehabilitation, namely restoring the child both medically, medicine and socially to the child,

\footnotetext{
17 Djamil, M. Nasir, (2013), Anak Bukan Untuk Dihukum, Jakarta: Sinar Grafika, Page, 65

18 Ibid, Page, 73

19 Rahardjo, Satjipto, (2009), Penegakan Hukum Suatu Tinjauan Sosiologis, Yogyakarta : Genta Publishing, page, 46
} 
restoring him through several phases or phases will make the child become a better person and in his protection the child must be given special protection that is protection will be which guarantees the best interests of a child, so that in service and care as well as guidance or counseling is very special. in law number 4 of 1979 concerning child welfare is stated Article 11 paragraph 1 it is stated that the efforts of child welfare consist of guidance, also development and prevention and rehabilitation, so that it is intended here that the addicted child from narcotics has the right to receive medical and social rehabilitation.

Protection of children who are specialized in recovering the condition as a drug addict must also be a concern of every agency, both from the government, social institutions, also from the community and even from the hospital where the child is treated and get treatment, meaning that in treatment must always prioritize and give priority to the existence of friendly to children, everything in prioritizing the best interests of children, which can be understood and felt by children ${ }^{20}$, and the service always prioritizes the needs for children, special needs and can be done by children with the results that are good so that the treatment is also good. Based on being friendly to children, especially towards children as drug offenders or addicts in the hope that and so that children can be completely cured of all addictions and be able to solve all their problems and the most important thing is not to repeat or fall into drugs, and attention should also be given too that if you have a problem both large and small, at least not by taking it out on drugs, because drugs are not a tool to solve or are good friends, but drugs are a great enemy of the nation, therefore stop drugs ${ }^{21}$.

Settlement of child disputes as narcotics offenders, although they are still classified as children, must still account for their actions because they are still under age, rehabilitation can be given to children. ${ }^{22}$ where in the provisions of article 1 paragraph (7) of Law Number 11 Year 2012 concerning the Child Criminal Justice System, the transfer of the settlement of a child case from a criminal justice process to a process other than criminal justice, while the definition of restoratif listed in Article 1 (6) includes children as a victim of narcotics abuse and with the provision of rehabilitation to children is to realize restorative justice for children, so that the implementation of rehabilitation for children is a form of punishment based on diversion based on child protection

\section{Conclusion}

\footnotetext{
20 Chaidir Ellydar, (2007), Hukum dan Teori Konstirusi, Yogyakarta : Kreasi Total Media, page, 30

21 Adam, Arlin, (2016), Rehabilitasi Narkoba dan Aids ; Memadukan Pendekatan Model Medis dan Model Sosial, Yogyakarta: Pustaka Pelajar, page. 12

22 Sutedjo, Wagiati, (2006), Hukum Pidana Anak, Bandung : RefikaAditama, page. 39
} 
Provision of rehabilitation for children is a form of punishment based on the concept of restorative justice in providing protection and welfare for children's rights, where by diversion there is a transfer of the process from formal to informal while continuing to provide the best interests of children, and in this concept also involves the community, actors and also victims in realizing justice in accordance with the children's institutional rights.

\section{References}

\section{Book}

Adam, Arlin, (2016), Rehabilitasi Narkoba dan Aids ; Memadukan Pendekatan Model Medis dan Model Sosial, Yogyakarta : Pustaka Pelajar

Djamil, M. Nasir, (2013), Anak Bukan Untuk Dihukum, Jakarta: Sinar Grafika Ellydar, Chaidir, (2007), Hukum dan Teori Konstirusi, Yogyakarta : Kreasi Total Media

Mardani, (2005), Penyalahgunaan Narkotika Dalam Perspektif Hukum Pidana Islam dan Hukum Pidana Nasional, Jakarta : Raja Grafindo

Marzuki, Peter Mahmud, (2009), Penelitian Hukum, Jakarta : Kencana

Prawoto, Budi dan Intari Dyah Pramudita, (2008), Narkotika dan Zat Adiktif, Jakarta : Sinar Grafika

Prodjodikoro, Wiryono, (2003) Tindak-Tindak Pidana Tertentu Di Indonesia, Bandung : Refika Aditama

Rahardjo, Satjipto, 2009, Penegakan Hukum Suatu Tinjauan Sosiologis, Yogyakarta : Genta Publishing

S. Amdinat, (2005), Upaya Pencegahan Narkoba Terhadap Anak Didik, Pekan baru : UNRI Press

Kusno, Adi, (2009), Kebijakan Kriminal Dalam Penanggulangan Tindak Pidana narkotika Oleh Anak, Malang: UMM Press

Sutedjo, Wagiati, (2006), Hukum Pidana Anak, Bandung : RefikaAditama

\section{Journal}

Andriansyah, Yuli, Lalu Abdurrahman, Penyuluhan Pencegahan Bahaya Narkoba Terhadap Anak-Anak Usia Dini, (2013), Jurnal Inovasi dan Kewirausahaan, 2 (2), Seri Pengabdian Masyarakat

Campa, Adriana, Sabrina Sales Martinez and Marianna Baum, (2017), Drug Addiction, Relapse and Recovery, Journal of Drug Abuse, vol. 3 (1:4), page, $1-2$

Hidayat, Asep Syarifuddin, Samul Anam, Muhammad Ishar Helmi, (2018), Perlindungan Hukum Terhadap Anak Sebagai Kurir Narkotika, SALAM ; Jurnal Sosial dan Budaya Syar-i, 5 (3)

Lichtblau Craig, Keith J Foster, Gabriele Melli, Charles H Hennekens (2019), Physical Medicine and rehabilitation : The Case For Physiatrists, International Jaournal Physical Medicine Rehabilitation, Vol. 7 (2), page, $1-3$

Novitasari, Dina, (2017), Rehabilitasi Terhadap Anak Korban Penyalahgunaan Narkoba, Jurnal Hukum Khaira Ummah, 12 (4) 
Purwatiningsih, Sri, Penyalahgunaan Narkoba Di Indonesia, (2001), Populasi Jurnal Kependudukan dan Kebijakan Universitas Gadjah Mada, 12 (1)

Tamutiene, Ilona, (2018), Alcohol-Related Child Maltreatment : Reports to the Child Rights Protection Services in Kaunas Municipalit, Nordic Studies on Alcohol and Drugs : SAGE Journals, vol. 35 (1), page, 9-23

\section{Internet}

https://www.galamedianews.com/?arsip=214151, "Dampak Negatif Penyalahgunaan Narkoba", diakses, 24 Januari 2020

https://www.hariansilampari.co.id/ratusan-remaja-direhabilitasi-narkoba/ "ratusan remaja direhabilitasi narkoba" diakses 26 Januari 2020

\section{Legislation}

Kitab Undang-Undang Hukum Pidana (KUHP)

Kitab Undang-Undang Hukum Acara Pidana (KUHAP)

Undang-Undang Nomor 39 Tahun 1999 Tentang Hak Asasi Manusia

Undang-Undang Nomor 35 Tahun 2009 Tentang Narkotika

Undang-Undang Nomor 4 Tahun 1979 Tentang Kesejahteraan Anak

Undang-Undang Nomor 11 Tahun 2012 Tentang Sistem Peradilan Pidana Anak (SPPA)

Undang-Undang Nomor 35 Tahun 2014 Tentang Perubahan Undang-Undang Nomor 23 Tahun 2002 Tentang Perlindungan Anak 